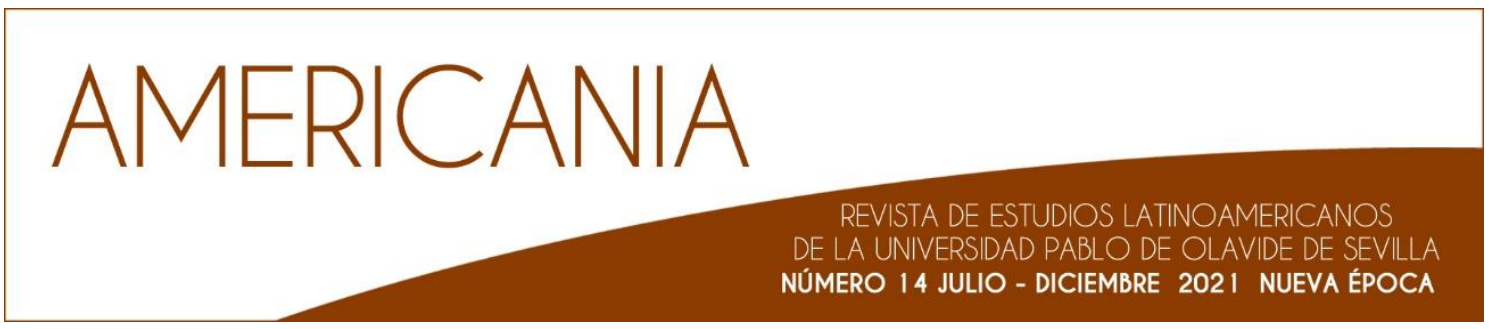

\title{
POSMODERNISMO, CAMBIO SEMÁNTICO E IMAGINARIOS POLÍTICOS EN LA PRÁCTICA HISTORIOGRÁFICA CONTEMPORÁNEA:
}

\section{A propósito del término 'colonia' en la historia de la Patagonia}

\section{Resumen}

En este artículo se analizan los modos en que el término 'colonia' ha sido contemplado, por ciertos historiadores que han estudiado el proceso de incorporación de la Patagonia al Estado argentino, como evidencia del carácter 'colonial' del régimen impuesto sobre dicha región. En tales estudios se comprueba una fuerte influencia de corrientes académicas que conciben al 'discurso' como la dimensión primordial de todo fenómeno social, lo que ha conducido a abordar las fuentes documentales como simples textos. El propósito de este artículo consiste, por un lado, en advertir los problemas resultantes de tal aproximación a las fuentes y, por el otro, en señalar los beneficios de una mirada atenta al cambio de los conceptos a través del tiempo. Se propone que la distinción de las capas semánticas depositadas en estos ofrece una barrera ante los peligros del textualismo, que lleva a reducir el pasado a un conjunto de articulaciones discursivas.

\section{Palabras Clave}

Historiografía - Crítica documental - Cambio conceptual - Estudios poscoloniales - Patagonia

1 Doctor en Ciencia Política por la Universidad Nacional de San Martín y Profesor en Historia por la Universidad Nacional del Comahue. Investigador Adjunto en el Consejo Nacional de Investigaciones Científicas y Técnicas de la Argentina (CONICET). Docente de la Universidad de Buenos Aires y de la Universidad Nacional de San Martín. Ha recibido distinciones de la Academia Nacional de la Historia y de la Asociación Argentina de Investigadores en Historia. 




\author{
POSTMODERNISM, SEMANTIC CHANGE, AND POLITICAL \\ IMAGINARIES IN THE CONTEMPORARY HISTORIOGRAPHICAL \\ PRACTICE:
}

About the Term 'Colony' in the History of Patagonia

\begin{abstract}
This paper examines how the term 'colony' has been considered, by some historians who had analysed the incorporation of Patagonia into the Argentine State, as evidence of the 'colonial' character of the regime imposed on that region. Those studies reveal a strong influence of academic trends that conceive 'discourse' as the primordial aspect of every social phenomenon, which has led to dealing with historical documents as mere texts. The purpose of this article consists, on the one hand, in acknowledging the problems resulting from such an approach to historical sources and, on the other hand, in pointing out the benefits of an attentive view to conceptual change through time. It is proposed that the distinction of semantic strata deposited in concepts offers a defense against the perils of textualism, which leads to reducing the past to an ensemble of discursive articulations.
\end{abstract}

\title{
Key Words
}

Historiography - Criticism of Documents - Conceptual Change - Postcolonial Studies - Patagonia 


\section{Introducción}

Alienígenas ancestrales es un programa televisivo dedicado a interpretar evidencias históricas y arqueológicas como indicios de pasados contactos humanos con civilizaciones extraterrestres. Emitido por el canal History y presentado por el nebuloso ufólogo suizo Giorgio A. Tsoukalos, el programa ha alcanzado quince temporadas a lo largo de casi diez años, durante los cuales ha logrado atraer la atención de millones de espectadores de todo el mundo. En la plataforma YouTube, la entrada Ancient Aliens -el nombre original del programa- permite advertir que sus episodios, o fragmentos de estos, totalizan también millones de vistas. Otras tantas suman las recibidas por las versiones dobladas a diferentes idiomas, bajo nombres como el provocador Nos ancêtres les extraterrestres o el más prudente Enigmi alieni. Desde perspectivas revisionistas sobre la misión Apollo XI, que buscan develar una verdad ocultada -nunca nadie habría llegado a la Luna-, hasta hipótesis más originales como la relativa a la existencia de pirámides en la Antártida, la oferta del programa es tan dispendiosa en especulaciones como carente de rigor científico.

La siempre mistificada Patagonia no podía escapar a esa audaz disposición. En uno de los episodios de la última temporada de la serie se discurre, sobre la sola base de la mitología selk'nam, en torno a posibles contactos de los indígenas fueguinos con seres extraterrestres, a los que habrían acostumbrado a representar mediante disfraces rituales, como los retratados en las conocidas fotografías del misionero alemán Martin Gusinde. Fascinado por esas fantásticas hipótesis de contactos ancestrales con alienígenas, un entusiasta y desprevenido seguidor de la serie podría alimentar similares conjeturas al hallar, por ejemplo, que en 1912, en el informe de la gira de estudio que realizó por encargo del Ministerio del Interior de la República Argentina, el sevillano Julio Navarro Monzó advertía a las autoridades sobre la presencia de "alienígenas" en la región patagónica².

Para desazón del imaginario prosélito de Tsoukalos, Navarro Monzó no hablaba de ninguna especie extraterrestre, sino de extranjeros establecidos en los territorios patagónicos. Según el uso establecido del vocablo en la lengua castellana a comienzos del siglo pasado, 'alienígena' era sencillamente sinónimo de extranjero.

\footnotetext{
2 Navarro Monzó, Julio, "Informe del secretario privado del señor Ministro del Interior, con motivo de su viaje a los Territorios de la Pampa, Neuquén, Río Negro, Chubut y Santa Cruz", en República Argentina-Ministerio del Interior, Primera Conferencia de los Gobernadores de Territorios Nacionales, Talleres gráficos de la Penitenciaría Nacional, Buenos Aires, 1913, 730.
} 
Así, por ejemplo, en su Historia de la América antecolombiana (1892), el historiador y político español Francisco Pi y Margall, cautivado por la calidad arquitectónica de antiguas ruinas andinas, se preguntaba si habían sido realizadas por "alienígenas, [aunque] difícil es explicar no solo de dónde vinieron sino también cómo y por qué se establecieron en Tiahuanaco"3, pero sin referirse a otra cosa que a muy terrestres pobladores arribados desde otras regiones. Asimismo, Miguel de Unamuno reflexionaba sobre la presencia de numerosos "vocablos alienígenas" en el idioma vasco4, mientras que el filólogo Arturo Campión se quejaba, en Bilbao, de que "la inmigración alienígena" amenazaba con convertir a los locales en "extranjeros en nuestra propia tierra" y denunciaba en Irún que, como consecuencia del mismo fenómeno, "cualquiera diría que el casco del pueblo es colonia alienígena"5.

La palabra 'alienígena' fue por primera vez incluida en el Diccionario de la lengua castellana de la Real Academia Española en 1803 y con una muy precisa definición: "lo mismo que extranjero"6. El vocablo retuvo estabilidad semántica durante todo el siglo XIX, como se comprueba en la decimotercera edición del Diccionario, publicada en 1899, en el que se lo definía como un adjetivo anticuado para significar "extranjero" y cuya etimología provenía de las voces latinas aliēnus (ajeno) y geněre (engendrar, nacer)7. Es necesario aguardar a 1992, año en que la misma academia publicó la vigesimoprimera edición del Diccionario de la lengua española, para ver por primera vez incluida una segunda acepción de la palabra 'alienígena', a saber, "extraterrestre, individuo de otro planeta"8. La introducción de tal significado suponía el reconocimiento académico de un uso ya establecido por los hispanohablantes, que para entonces habían contemplado por décadas, en las viñetas de cómics, en las salas de cine o en las pantallas de sus televisores, innumerables seres extraterrestres, de los más variados aspectos, niveles de desarrollo tecnológico y actitudes hacia la especie humana. En la actualidad, el de extranjero se mantiene todavía en el ámbito lingüístico hispánico como el otro significado de 'alienígena', aunque en franco desuso en razón del cambio semántico operado en el vocablo durante el siglo XX. Sin restituir en forma adecuada los sentidos con que los

\footnotetext{
Pi y Margall, Francisco, Historia de la América antecolombiana, 2 vols., Montaner y Simón, Barcelona, 1892, 1: 324. Unamuno, Miguel de, Ensayos, 7 vols., Publicaciones de la Residencia de Estudiantes, Madrid, 1916-1918, III: 106. Campión, Arturo, Discursos políticos y literarios, Imprenta y Librería de Erice y García, Pamplona, 1907, 121 y 182. Real Academia Española, Diccionario de la lengua castellana, Viuda de Ibarra, Madrid, 1803, 48.

Real Academia Española, Diccionario de la lengua castellana, Imprenta de los señores Hernando y compañía, Madrid, $1899,48$.

8 Real Academia Española, Diccionario de la lengua española, Espasa-Calpe, Madrid, 1992, 72.
} 
actores pretéritos utilizaron el término, el deseo de ver confirmada una presuposición podría conducir a un lector precipitoso a creer que, cuando Navarro Monzó sugería promover "la selección del alienígena", hablaba de preferir unos seres extraterrestres a otros.

Por supuesto, ningún historiador incurriría en un malentendido semejante. El caso imaginario ilustra de forma patente algo bien sabido, esto es, que las palabras suelen cambiar de sentido a lo largo del tiempo. Pero las cosas se tornan algo más complejas cuando se trata de conceptos. Como las palabras, estos son también polisémicos. Sin embargo, de acuerdo con la formulación de Reinhart Koselleck, mientras que "una palabra contiene posibilidades de significado, un concepto unifica en sí la totalidad del significado"10. Una palabra significa cosas, pero un concepto es en cambio un depósito de "la totalidad de un contexto de experiencia y significado sociopolítico"11, un recipiente que se constituye en el acopio de los "contenidos de experiencia que se han acumulado en el concepto"12. Estos sedimentan, según la conocida metáfora geológica de Koselleck, en la forma de "estratos semánticos"13, cuya diferenciación constituye un aspecto fundamental de la práctica historiográfica. Cuando no son discriminados de forma adecuada, no solo se enfrenta el peligro del anacronismo, que implica atribuir a los actores pretéritos usos y sentidos inconcebibles dentro de su campo de experiencia, sino también el de confundir sentidos disímiles aunque contemporáneos del mismo concepto, originados en experiencias distantes en el tiempo, pero que permanecen disponibles a los actores que los emplean. Por otra parte, si no se advierte la historicidad de los diversos sentidos concentrados en un concepto, se corre además el riesgo de incurrir en proyecciones retrospectivas que naturalizan significaciones que el concepto solo alcanzó al cabo de la acumulación de posteriores experiencias históricas. Un manejo del concepto que no consiga distinguir los estratos semánticos depositados en él entraña el peligro de convertir a quien explora el pasado en vehículo involuntario de específicas

9 Monzó, Julio, "Los tres problemas del momento político actual", Revista Argentina de Ciencias Políticas, Buenos Aires, no. VI, 1913, 17.

10 Koselleck, Reinhart, Futuro pasado. Para una semántica de los tiempos históricos, Paidós, Barcelona, 1993 [1979], 117.

11 Ibid.

12 Koselleck, Reinhart, Historias de conceptos. Estudios sobre semántica y pragmática del lenguaje político y social, Trotta, Madrid, 2012 [2006], 46.

13 Koselleck, Reinhart, Sediments of Time. On Possible Histories, Stanford University Press, Stanford, 2018 [2000], 3. 
significaciones político-ideológicas, que resultan así transportadas mucho más allá de la temporalidad por la que están determinadas.

Estos riesgos se han visto incrementados por el influjo de ciertas corrientes intelectuales, hegemónicas en ciertos ámbitos, que reducen la historia a una serie de articulaciones lingüísticas e incitan así a un modo textualista de aproximación al pasado, en el que un aspecto central de la práctica historiográfica, como la crítica detenida de la evidencia empírica, queda relegado como mero residuo de objetivismo decimonónico ${ }^{14}$, cuando no diagnosticado como síntoma de una patología epistemológica ${ }^{15}$. Según estas miradas, la constitución de la historia como disciplina resultó de una pretensión de verdad acerca del pasado, lo que no solo reflejaría su inscripción 'epistémica' en la modernidad, sino además su condición de estructura misma del saber moderno ${ }^{16}$. De allí que la impugnación de este como una fuerza coactiva sobre el sujeto se traduzca en el rechazo de la historia, acusada de no ofrecer más que una ilusoria veracidad en la forma de la serie temporal17. El imperativo no radicaría ya en comprender el pasado -vana intención de la historia-, sino en describir 'discursos', pero sin buscar nada más allá de estos, puesto que nada habría fuera de ellos ${ }^{18}$. Así, "la descripción de las formaciones discursivas"19 o el ejercicio de "un positivismo alegre"20 -es decir, uno desprovisto de rigor por los hechos-serían métodos capaces de develar relaciones de poder que no podrían ser bien advertidas por la historia, ocupada como estaría en la confección de imaginarias correspondencias entre signos, objetos y acontecimientos. Desde tales presunciones, la condición de la historia como representación verídica del pasado ha sido objeto de cuestionamientos radicales, para los cuales la historiografía constituiría un discurso en su aspecto formal indistinguible de la literatura, no solo por su carácter narrativo21, sino también -según formulaciones más recientes- porque "los hechos históricos son inventados, sobre la base del estudio de los documentos, sin duda, pero no obstante

14 Foucault, Michel, Las palabras y las cosas. Una arqueología de las ciencias humanas, Fondo de Cultura Económica, México, 2002 [1966].

15 Derrida, Jacques, Mal de archivo. Una impresión freudiana, Trotta, Madrid, 1997 [1995].

16 Foucault, Michel, Las palabras, 214-215.

17 En los estrictos términos de Sylvie Le Bon, el propósito de Michel Foucault en Las palabras y las cosas consiste en suprimir la historia y para ello busca "no pensar en la historia. Excluirla, si no de lo real, por lo menos del saber". Véase Le Bon, Sylvie, "Nota preliminar. Un positivista desesperado: Michel Foucault", en Foucault, Michel, Saber, historia y discurso, Prometeo, Buenos Aires, 2015, 9.

18 Foucault, Michel, La arqueología del saber, Siglo XXI, Buenos Aires, 2003 [1969], 235.

19 Foucault, Michel, La arqueología del saber, 223.

20 Foucault, Michel, El orden del discurso, Tusquets, Buenos Aires, 1992 [1970], 57.

21 White, Hayden, Metahistoria. la imaginación histórica en la Europa del siglo XIX, Fondo de Cultura Económica, México, 1992 [1973], 14. 
inventados"22. En suma, se puede sostener que la premisa común a los enfoques posmodernos acerca de la historia consiste en postular, como han advertido voces críticas de esas perspectivas, que "la búsqueda de la verdad se puede considerar la principal ilusión de Occidente"23.

En este artículo no se aspira a poner de relieve las implicancias de las filosofías lingüísticas sobre la práctica historiográfica, que han ayudado a sofisticar la forma de entender el lugar del lenguaje en ella, aunque también han derivado en los gestos posmodernos de reducir la sociedad a un efecto de "juegos de lenguaje"24 y la historia a "un producto del discurso y la discursivización"25. La reflexión que aquí se propone deriva más bien de la preocupación por evidenciar los modos en que el prestigio, justificado o no, de ciertas corrientes académicas, induce a sus seguidores, en forma acaso inadvertida, a enfrentar los documentos como simples textos cuyas superficies ofrecerían palabras de plena transparencia semántica y además coincidentes con los significados que se les atribuye dentro de una cierta teoría.

Que el examen detenido de los documentos constituye un aspecto quizá tradicional, pero ineludible, en la práctica historiográfica ha sido subrayado entre otros por el propio Koselleck, al recordar que la historia conceptual "es en primer lugar un método especializado para la crítica de las fuentes"26, que por supuesto no se reduce a la determinación de la autenticidad de un documento dado. No se trata entonces de rendir ofrenda al "culto de lo fáctico" objetado por Quentin Skinner27, pero sí de advertir los riesgos de lanzarse a los 'discursos' identificados en los documentos sin primero ejercer sobre estos un examen detenido. Esto puede parecer anticuado para una vida académica permeada por otro culto -el de la novedad-, pero permanece como una condición imprescriptible de la buena práctica historiográfica. Un abordaje superficial de los documentos, que se limita a recorrer su exterioridad textual en busca de palabras clave, comporta entre otros el peligro de reducir la investigación histórica a una función ilustrativa de interpretaciones que, por

22 White, Hayden, El texto histórico como artefacto literario y otros escritos, Paidós, Buenos Aires, $2003,53$.

23 Appleby, Joyce; Hunt, Lynn y Jacob, Margaret, La verdad sobre la historia, Andrés Bello, Santiago de Chile, 1999 [1995], 200.

24 Lyotard, Jean-François, La condición postmoderna, REI Argentina, Buenos Aires, 1995 [1979], 37-38.

25 White, Hayden, El texto histórico, 43.

26 Koselleck, Reinhart, Futuro pasado, 112.

27 Skinner, Quentin, Lenguaje, política e historia, Universidad Nacional de Quilmes, Bernal, 2007 [2002], 33-61. 
estar académicamente consagradas, son dadas por válidas al margen de toda rigurosidad empírica.

Desde la década de 1980, momento de su consagración en las principales universidades de los Estados Unidos, los llamados estudios poscoloniales, una corriente intelectual nacida de la crítica literaria y luego trasladada a otras disciplinas, no han dejado de ganar terreno gracias a una ingente financiación de publicaciones, proyectos de investigación y programas de posgrado. Razones de espacio impiden ofrecer un panorama detallado de la literatura poscolonial, dar cuenta de sus raíces político-intelectuales o ensayar una revisión de sus premisas teóricas, de las que cabe de todos modos señalar su origen en el postestructuralismo ${ }^{28}$. La entusiasta recepción que esa literatura ha encontrado en las últimas décadas en el ámbito de la historia, al encontrar en aquella una crítica radical de la modernidad occidental y una vía de escape a toda acusación de complicidad con ella -eurocentrismo, etnocentrismo, nacionalismo, racismo, etc.-, ha tenido importantes consecuencias, no siempre positivas, sobre la práctica historiográfica29. Frente al atractivo político-ideológico de esa literatura, la crítica documental que representó un pilar en la constitución de la historia como disciplina queda con frecuencia relegada como una práctica anticuada, que no advierte la naturaleza discursiva común a toda fuente y a toda historiografía, algo en cambio subrayado por una crítica literaria que se permite así transitar entre ambas como por sobre una superficie textual homogénea. La actitud posmoderna hacia los documentos deja de contemplarlos como vestigios del pasado mediante cuyo examen crítico se vuelve posible conocerlo -principio defendido por diversos autores30-, para seguir en cambio a quienes predican superar la idea del "documento, como signo de otra cosa", e invitan a limitarse a la descripción del "discurso en su volumen propio"31. En el caso de la corriente poscolonial, la preeminencia que en ella no ha dejado de tener el modelo metodológico de la crítica literaria parece haber incentivado en alguna historiografía cierta disposición a

28 Acerca de esos aspectos de la corriente poscolonial: Young, Robert C. J., "Nuevos recorridos por (las) Mitologías blancas", en Mezzadra, Sandro ed., Estudios poscoloniales. Ensayos fundamentales, Traficantes de sueños, Madrid, 2008, 216; Mellino, Miguel, La crítica poscolonial. Descolonización, capitalismo y cosmopolitismo en los estudios poscoloniales, Paidós, Buenos Aires, 2008.

29 Una mirada crítica sobre el impacto de esas corrientes en la historiografía, en: Windschuttle, Keith, The Killing of History. How Literary Critics and Social Theorists are Murdering Our Past, The Free Press, New York, 1996.

30 Chartier, Roger, On the Edge of the Cliff. History, Language, and Practices, John Hopkins University Press, Baltimore, 1997, 25-26. Oakeshott, Michael, Sobre la historia y otros ensayos, Katz, Buenos Aires, 2013, 61-62. Koselleck, Futuro pasado, 199-200.

31 Foucault, Michel, La arqueología, 233-234. Itálicas en el original (Nota del editor: en referencia a la palabra aqui subrayada) 
tratar a las fuentes como expresiones inmediatas de poder, con la consecuencia de tomar la terminología de un documento como un puente directo entre el pasado y las categorías teóricas de las que se sirve la investigación. En lo que sigue, este artículo ofrece una reflexión sobre esas dificultades, pero a partir de las que surgen en torno a un término de mayor amplitud semántica que el expuesto al comienzo, y que ocupa además el lugar central en aquella literatura, a saber, el de 'colonia'.

Es importante establecer que no se busca ensayar una historia conceptual del término -aunque será necesario decir algo sobre los cambios registrados en él a lo largo del tiempo-, ni tampoco dar minuciosa cuenta de las variaciones en los modos en que dicha voz ha sido utilizada por la historiografía. Se trata, más bien, de ilustrar las dificultades antes señaladas a partir del caso específico de los usos que el vocablo 'colonia' ha recibido en cierta reciente historiografía sobre aquella misma región en la que Navarro Monzó halló 'alienígenas', la Patagonia, a la que tanto él como otros observadores retrataron como sujeta a un régimen 'colonial' y cuyas impresiones han llegado a ser tomadas -se observará más adelante- como prueba de tal condición. Resulta imperioso advertir que no se busca aquí analizar si es o no válido definir como 'colonial' al régimen que funcionó en esa región desde las décadas finales del siglo XIX, momento de su efectiva incorporación al dominio del Estado argentino, hasta mediados del siglo pasado, cuando se crearon en ella nuevas provincias ${ }^{32}$. Lo que se pretende mostrar son los riesgos que entraña una aproximación textualista a los documentos históricos, que se afirma en el hallazgo de una palabra -'colonia'- para dar por probada la existencia de una condición 'colonial', sin someter la evidencia a un examen más riguroso. Entre los peligros de tal disposición, no es el menor el de disipar el carácter histórico de los conceptos y convertirlos en vehículos de sentidos ideológico-valorativos transportados, acaso de forma involuntaria, por el historiador.

\section{Patagonia poscolonializada}

En la historiografía argentina, los ya extintos Territorios Nacionales ofrecen una materia que parece ajustarse en todo a los enfoques promovidos por la literatura poscolonial, a la que se ha atribuido el haber otorgado "nuevas dimensiones al

32 Desde una perspectiva poscolonial se ha concluido, naturalmente, que la Patagonia estuvo entonces sujeta a un régimen colonial. Véase: Harambour, Alberto, Soberanías fronterizas. Estados y Capital en la Colonización de Patagonia (Argentina y Chile, 1830-1922), Universidad Austral de Chile, Valdivia, 2019. 
término colonial", creyendo así posible trasladar ese análisis "a ámbitos no concebidos, al menos formalmente, como colonias"33. El Chaco, la Pampa y la Patagonia, los grandes espacios sobre los que aquellas unidades fueron creadas, habían permanecido por siglos al margen de la autoridad imperial española y no sería sino hacia 1880, en un periodo marcado en el nivel local por la consolidación del Estado argentino y en el internacional por la madurez del imperialismo europeo, cuando se produjo el definitivo sometimiento de los grupos aborígenes de aquellas vastas extensiones. Los espacios así incorporados quedaron bajo control del Estado federal y fueron organizados en la forma de Territorios Nacionales, es decir, como unidades administrativas dependientes del gobierno nacional, que designaría sus autoridades hasta que reuniesen las condiciones necesarias para su admisión como nuevas provincias. Mientras eso no se produjese, los Territorios no podrían gobernarse a sí mismos, no dispondrían de representación en el Congreso de la Nación y tampoco contarían con participación en las elecciones nacionales.

Como puede advertirse, la historia de los Territorios parece materia propicia para un abordaje de inspiración poscolonial. En ella se combinan la conquista territorial en nombre de la civilización, el sometimiento o bien la desaparición de culturas ajenas a la modernidad occidental, e incluso la imposición de una forma centralizada de gobierno que no concedió inmediata autonomía a esos espacios. Esa lectura se ha creído respaldada por obras que, desde la crítica literaria posmoderna, se propusieron explorar "la misión civilizadora con respecto a África" y encontraron en ella "el mismo lenguaje aplicado a los pueblos poscoloniales de la América española", para contemplar ambas experiencias como producto de la enunciación de un mismo "discurso colonial"34. La identificación de este último en las descripciones del espacio patagónico elaboradas a finales del siglo XIX permitiría considerar el caso argentino como una reverberación austral del mismo fenómeno representado por las posesiones imperiales europeas en Asia y África. Esto daría cuenta de la continuidad de un mismo 'proyecto colonial', nacido de la modernidad occidental, que explicaría que "la elite liberal argentina deseaba emular las prácticas

33 Zusman, Perla, “La alteridad de la nación. La formación del Territorio del Noroeste del Río Ohio de los Estados Unidos (1787) y de los Territorios Nacionales en Argentina (1884)", Documents d'Anàlisi Geogràfica, Barcelona, no. 56, 2010, 506.

34 Pratt, Mary Louise, Ojos imperiales. Literatura de viajes y transculturación, Fondo de Cultura Económica, Buenos Aires, 2011 [1992], 283. Usos de ese modelo en la historiografía patagónica en: Navarro Floria, Pedro, comp., Patagonia: ciencia y conquista. La mirada de la primera comunidad científica argentina, Publifadecs, General Roca, 2004. 
de exploración y apropiación territorial que los países europeos estaban llevando adelante en Asia o África"35.

La diferencia entre los colonialismos europeos desplegados en aquellos continentes y la experiencia de naciones como Argentina, surgida de la disolución del imperio español, radicaría en el devenir de una excolonia en un poder 'colonial'. Se trataría por esto de un "colonialismo poscolonial"36 -también identificable en buena parte de los estados americanos y en otros como Australia- que explicaría por qué los Territorios no fueron de inmediato convertidos en provincias y quedaron en cambio bajo la administración directa del gobierno nacional. La razón habría radicado en la vigencia de un 'principio colonial' que exigía la negación de los derechos políticos con el argumento de que "tanto la población como el territorio anexado carecen de madurez cívica"37. Por otra parte, ese 'colonialismo', que lo sería por ser ejercido sobre tierras conquistadas a los aborígenes, constituiría a su vez el origen de otro, un 'colonialismo interno', en el que los Territorios constituirían las 'colonias' de una 'metrópoli' localizada en la ciudad de Buenos Aires y decidida a negarles el goce de un gobierno autónomo para perpetuar así la expoliación de sus recursos ${ }^{38}$. Todo esto ha llevado a concluir que "la postergación deliberada de la integración de los Territorios en la vida política plena formaba parte [...] de su consideración como colonias internas de la Nación"39.

Los aparentes paralelismos entre la experiencia de un Estado nacional y la de los imperios europeos ultramarinos -además contemporáneas- parecerían comprobar el carácter 'colonial' de los Territorios, que no haría más que ratificarse en fuentes en las que se habla de estos como 'colonias'. Así se ha querido ver, por ejemplo, en los debates parlamentarios que tuvieron lugar en el Congreso de la Nación en 1898, con motivo de una nueva ley de ministerios del Poder Ejecutivo. En efecto, se ha sostenido que mientras algunos legisladores proponían concentrar los asuntos de los Territorios en el Ministerio de Agricultura, otros adoptaban el criterio,

35 Zusman, Perla, "La alteridad", 520.

36 Harambour, Alberto, "Monopolizar la violencia en una frontera colonial. Policías y militares en Patagonia austral (Argentina y Chile, 1870-1920)", Quinto Sol, Santa Rosa, XX, no. 1, 2016, 3.

37 Ibid.

38 Navarro Floria, Pedro, “La 'República posible' conquista el 'desierto'. La mirada del reformismo liberal sobre los Territorios del Sur argentino", en Navarro Floria, Pedro, coord., Paisajes del progreso. La resignificación de la Patagonia norte, 1880-1916, Educo, Neuquén, 2007, 219.

39 Navarro Floria, Pedro y Núñez, Paula Gabriela, “Un territorio posible en la República imposible. El Coronel Sarobe y los problemas de la Patagonia argentina", Andes, Salta, XXIII, no. 2, 2012, 296. 
supuestamente más conservador, de considerar a dichos espacios como 'colonias' de la nación ${ }^{40}$. Sin embargo, quien proponía lo primero era quien sostenía lo segundo. Al justificar por qué sugería encomendar al Ministerio de Agricultura todo lo relativo a los Territorios, el senador Rafael Igarzábal explicaba que su propósito era que dicha cartera "venga a ser algo así como el ministerio de colonias en Europa"41. Por su parte, quienes se referían a los Territorios como "colonias de la nación" y habrían por eso sostenido la postura supuestamente conservadora de mantenerlos bajo la dependencia del Ministerio del Interior, como el diputado Mariano de Vedia, veían en aquellas unidades "porciones del territorio de la nación, uno e indivisible en su soberanía y en su dominio [...] sujetas a la constitución y a las leyes generales", y por lo tanto como "futuras provincias, que han de venir a engrandecer la nación" 42 . Vale decir, la supuesta mirada 'colonial' contemplaba sin embargo a los Territorios como parte integral de la nación, destinados a convertirse en miembros del pleno derecho del régimen federal, y no encontraba necesario gobernarlos mediante leyes especiales del tipo de las dictadas por los imperios europeos para sus posesiones de ultramar43.

La propuesta, en realidad formulada por Igarzábal, de tomar a las burocracias coloniales de los imperios europeos como modelo administrativo a seguir, se ha creído refrendada por Estanislao Zeballos, quien en 1899 y ya apartado de la vida política por disputas con el presidente Julio A. Roca, se quejaba, desde su Revista de Derecho, Historia y Letras, de que la nación argentina no había formado, "como la Gran Bretaña y el Imperio Alemán, gobernadores y empleados especiales para la administración colonial", lo que entendía conspiraba contra un mejor gobierno de los Territorios44. Reclamaba así imitar "a esos grandes estados colonizadores" para asegurar que el gobierno de aquellos espacios quedara a cargo de "personas de aptitudes intelectuales, de arraigo social, de carácter moral intachable, de visiones patrióticas y si fuera posible, de prestigiosa tradición administrativa"45. La intervención

40 Navarro Floria, Pedro, "La nacionalización fallida de la Patagonia Norte. 1862-1904", Quinto Sol, Santa Rosa, VII, no. $1,2003,80$.

41 Diario de Sesiones de la Cámara de Senadores de la Nación Argentina (DSCS), 1898, 63.

42 Diario de Sesiones de la Cámara de Diputados de la Nación Argentina (DSCD), 1898, I: 460.

43 Conviene subrayar que lo señalado por De Vedia no era una simple opinión. La diferencia más fundamental es que todos los nacidos en los Territorios, indígenas incluidos, eran legalmente ciudadanos de la nación, lo que por ejemplo no ocurría en las colonias europeas en África y Asia. Sobre estos últimos casos: Fradera, Josep, Gobernar colonias, Península, Barcelona, 1999.

44 Zeballos, Estanislao, "De Magallanes a la Puna", Revista de Derecho, Historia y Letras, Buenos Aires, I, no. 3, 1899, 310.

45 Ibid. 
de Zeballos no constituiría una más entre las muchas acusaciones que un publicista podía lanzar contra el gobierno, sino que reflejaría "un marco institucional en el que se considera a los Territorios como colonias internas" 46.

La existencia de una mirada 'colonial' sobre los Territorios también se ha querido deducir de que nada menos que Felipe Yofre, ministro de Interior del presidente Roca, sostuvo, en una memoria ministerial de 1900, que "los Territorios, amplios desiertos destinados a poblarse por la inmigración europea, constituyen propiamente colonias administradas por la Nación" 47 , y se añadieron itálicas a la cita 48 con el ánimo de enfatizar aquello que se quería ver corroborado por ella, esto es, que los Territorios eran "considerados abiertamente como colonias"49. Las expresiones de Yofre revelarían que el propósito del gobierno nacional de reformar la Ley de Territorios de 1884 apuntaba a establecer "un dispositivo de explotación colonial más eficaz que el ideado previamente [y a] acentuar su carácter de espacios coloniales internos" 50 . Algo que podría creerse confirmado por el hecho de que, a diferencia de lo previsto en dicha ley, que dictaba la futura transformación de los Territorios en nuevas provincias, el proyecto impulsado por Yofre -mas nunca aprobado- omitía cualquier cláusula relativa a tal evolución.

Todos estos pasajes han sido esgrimidos como evidencias de que en los círculos gubernamentales y letrados del fin de siglo los Territorios eran considerados 'colonias', al modo de aquellas que las potencias europeas tenían en otros continentes. El uso público que funcionarios del más alto rango hicieron de la palabra 'colonia' para referirse a los Territorios ha sido tomado como prueba del desparpajo con el que 'la elite dominante' proyectaba sobre estos una mirada 'colonial', interesada en perpetuarlos bajo "un régimen de colonialismo interno", en lugar de reconocerlos en forma inmediata como nuevas provincias ${ }^{51}$. Como ya fue adelantado, no se busca aquí establecer si es apropiado entender a los Territorios como 'colonias' o si es válido caracterizar a su forma de gobierno como un "régimen político de colonialismo

46 Navarro Floria, Pedro, "La 'República posible”", 222.

47 Navarro Floria, Pedro, "La nacionalización", 83. Itálicas en el original.

48 Nota del editor: en la sección que aparece aquí subrayada.

49 Navarro Floria, Pedro, "La nacionalización", 84. La misma cita y el mismo énfasis en Navarro Floria, Pedro, "El conocimiento de los Territorios Nacionales generado por los agentes del Estado: memorias, informes y mapas", en Podgorny, Irina; Penhos, Marta y Navarro Floria, Pedro, Espacios y cuerpos en la Argentina del siglo XIX y comienzos del XX, Biblioteca Nacional-Teseo, Buenos Aires, 2007, 104.

50 Navarro Floria, Pedro, "El conocimiento...", 99.

51 Navarro Floria, Pedro, “La nacionalización”, 83-84; Navarro Floria, Pedro, “El conocimiento", 104. 
interno"52. Antes bien, interesa analizar si las palabras contenidas en testimonios documentales como los mencionados pueden ser sin más contempladas como prueba del carácter 'colonial' que se quiere ver confirmado. ¿ेPuede, entonces, el uso de la palabra 'colonia' ser tomado como evidencia de una condición o siquiera de una mirada 'colonial'?

Algunos años más tarde, en el mismo informe en el que señalaba la presencia de 'alienígenas' en la Patagonia, Navarro Monzó insistía en sugerir, como solución al desorden administrativo que juzgaba comprometía el progreso de las gobernaciones, centralizar todos sus asuntos en un Ministerio de Territorios que, "ocupando el puesto que en las potencias europeas tiene el Ministerio de Colonias o el Ministerio de Ultramar, tenga a su cargo todas las necesidades de las Gobernaciones"53. Dado el gobierno del Estado nacional sobre esos espacios, que calificaba de "régimen colonial", Navarro Monzó sostenía que los Territorios "son meras colonias suyas y colonias de las más desprotegidas o en primer grado de evolución, porque no tienen siquiera lo que han tantas posesiones francesas, inglesas y portuguesas: representación en el Parlamento"54. Navarro Monzó advertía que su descripción no era evidente y reconocía la existencia de argumentos contrarios al suyo, según los cuales los Territorios no eran colonias puesto que formaban parte del mismo suelo argentino. Encontraba así necesario explicar -en un pasaje que merece ser citado en extenso-que:

"lo que da carácter de colonia a un país no es su separación de la metrópoli: a nadie se le ocurrió hasta ahora decir que Irlanda o Córcega sean una colonia inglesa y una colonia francesa, respectivamente, e inversamente nadie niega que el Turquestán y la Manchuria septentrional sean colonias rusas.

Lo que imprime el sello del vasallaje es la desigualdad de tratamiento -que es precisamente lo que pasa entre los habitantes de los Territorios Nacionales y los de las Provincias y la Capital. Lo que da carácter colonial es la diferencia de los derechos políticos de los pobladores de la colonia con respecto a los de la metrópoli, diferencia que tiene siempre por base una inferioridad de raza o de

\footnotetext{
52 Navarro Floria, Pedro, "La mirada del reformismo liberal sobre los Territorios del Sur argentino, 1898-1916", Quinto Sol, Santa Rosa, no. 13, 2009, 91.

53 Navarro Monzó, Julio, "Informe", 685.

54 Navarro Monzó, Julio, "Informe”, 694.
} 
cultura y que desaparece tan pronto como el número de habitantes de raza superior ha alcanzado un cierto nivel" 55 .

Para Navarro Monzó, un régimen colonial no era condenable por el hecho de serlo. En sus palabras, "los habitantes de una colonia, por ser étnicamente inferiores negros, pardos o amarillos, ipoco importa al legítimo orgullo de la raza aria!- no son ciudadanos, son súbditos"56. A su entender, esto permitía o incluso hacía necesario un gobierno colonial. Pero se preguntaba de inmediato:

"¿ipuede legítimamente, puede justamente establecerse esta diferencia para esos pedazos del suelo argentino que aun cuando fueron -como lo son generalmente las colonias- conquistados por la espada, están habitados por una mayoría tan aplastante de hombres de raza blanca que hace imperceptible y casi invisible el antiguo elemento autóctono?"57

Para Navarro Monzó, la situación de los Territorios era injusta no porque eran administrados por funcionarios designados por el gobierno federal, sino porque los argentinos que allí habitaban no tenían representación en la Cámara de Diputados, ni parte en la elección del Presidente de la Nación. Si bien no desconocía que esta situación era similar a la de los territorios federales de los Estados Unidos, en cuya experiencia federal abrevaba la República Argentina, llamaba a ir más allá del modelo del norte, reclamando "ique se haga aquí un paso más adelante [...] y que se dé satisfacción a los justos deseos de los argentinos del sur, porque de ese modo se habrá adelantado mucho en la obra de nacionalización de aquellos Territorios!"58.

Como puede observarse, Navarro Monzó empleaba la voz 'colonia' con el propósito de denunciar una situación que encontraba injusta y que él mismo admitía no entender, al ver un "contrasentido palpable" en que la Constitución argentina establecía que el número de diputados debía fijarse según una base demográfica, pero al mismo tiempo solo permitía participar en las elecciones nacionales a los argentinos radicados en las provincias y en la Capital Federal59. No cabe ahora explicar los motivos por los cuales el sistema representativo entonces vigente limitaba a las provincias y a la Capital Federal la participación en la formación de los poderes

5 Navarro Monzó, Julio, “Informe”, 695.

56 Ibid.

57 Ibid.

58 Ibid.

59 Ibid. 
de gobierno. Interesa más señalar que el carácter 'colonial' que Navarro Monzó atribuía a los Territorios no derivaba de que estos no se gobernaban a sí mismos, sino de lo que observaba como un tratamiento desigual hacia los iguales, es decir, los ciudadanos argentinos allí radicados. Mientras que un régimen colonial era aceptable para gobernar poblaciones juzgadas étnica o culturalmente inferiores, no lo era en el caso de aquellas de la misma calidad que la del resto del país. En definitiva, cuando Navarro Monzó calificaba de 'colonias' a los Territorios buscaba menos ofrecer una descripción de estos que condenar lo que entendía como una condición degradada de espacios que eran parte de la nación. En otros términos, no afirmaba que los Territorios eran 'colonias', sino que los juzgaba tratados como tales, reducidos a una condición inferior a la que entendía merecían. Se advierte así la necesidad de discriminar las capas semánticas del concepto para identificar los diversos usos que los actores podían hacer del mismo, entre los que cabía también uno metafórico como el practicado por Navarro Monzó.

\section{Breve excurso lexicográfico}

En el mismo informe de 1912 en el que empleaba el término 'colonia' para equiparar la situación de los Territorios con la de las posesiones ultramarinas de los imperios europeos, Navarro Monzó utilizaba la misma palabra para referirse a otras cosas. Por ejemplo, para señalar, luego de recorrer el valle de Paso de Indios, la necesidad de "establecer una colonia -hace mucho proyectada- que dignamente aproveche los fértiles campos que el río Chubut baña"60. También para dar cuenta de su paso por "la colonia más rígidamente abstemia, como la de 16 de Octubre", en el valle superior de aquel río, y para hacer lo propio de su visita a "la colonia israelita rusa" fundada en Bernasconi, La Pampa61. Asimismo, para recomendar la prohibición de la venta de bebidas alcohólicas "en las colonias indígenas y hasta dos leguas de distancia de ellas", y para adoptar medidas similares "en toda otra colonia, siempre que más de diez vecinos lo pidan"62. De igual modo para sugerir, como medio de nacionalización de espacios con mayoría de población chilena, la formación "en la

Navarro Monzó, Julio, "Informe”, 717.

61 Navarro Monzó, Julio, "Informe", 721-723.

62 Navarro Monzó, Julio, "Informe", 726. 
zona fronteriza [de] tantas colonias compuestas exclusivamente de argentinos nativos cuantas sea posible formar"63.

En todos esos casos, 'colonia' era el término para designar un poblado surgido de un asentamiento diagramado ex profeso sobre tierras disponibles a tal efecto, con el fin de promover la radicación de población y la explotación de los recursos productivos existentes en cada caso. Como anotaba Lucio V. López, titular de la cátedra de Derecho Constitucional en la Universidad de Buenos Aires, "la Nación se ha hecho cargo de la formación de colonias en los territorios nacionales y aun se han creado colonias en territorios provinciales"64. Agrícolas, pastoriles o penales; públicas o privadas; integradas por indígenas, inmigrantes o argentinos; la noción de 'colonia' comprendía todas esas formas posibles de radicación planificada de población. Pero además de emplearlo de ese modo descriptivo, Navarro Monzó también daba al término un uso retórico para denunciar la desatención de las autoridades nacionales hacia esas regiones y sostener así que "es anti-argentino un estado de cosas que prácticamente hace que todos los territorios del sur sean como colonias de Europa"65. En resumen, Navarro Monzó entendía que los Territorios, en los que reconocía la existencia de distintas 'colonias', eran destratados por las autoridades nacionales como 'colonias', al mismo tiempo que denunciaba como 'colonias' europeas a los asentamientos de extranjeros allí presentes. Todos esos bien establecidos sentidos, procedentes de experiencias históricas distantes en el tiempo, pero en contemporánea disponibilidad, podían ser conjugados de forma simultánea sin necesidad de especificar cuál de ellos correspondía a cada uso.

Resulta útil entonces poner en evidencia la carga semántica que el vocablo 'colonia' había acumulado para la época en que Navarro Monzó desplegaba ese uso polisémico. Un modo de aproximarse a ello es dar cuenta de los cambios en los registros lexicográficos. Por supuesto que se trata de una vía imperfecta que no se insinúa sustituta de una historia conceptual, en tanto esta "no puede limitarse nunca a los significados de las palabras y su modificación"66. Pero como ya fue adelantado, el propósito de estas páginas no es avanzar en una historia conceptual del término. Además, las definiciones reunidas en un diccionario nunca dan cuenta de todas las

\footnotetext{
63 Navarro Monzó, Julio, “Informe”, 738.

64 López, Lucio V., Derecho administrativo argentino, Imprenta de La Nación, Buenos Aires, $1902,193$.

65 Navarro Monzó, Julio, "Informe”, 719.

66 Koselleck, Reinhart, Futuro pasado, 119.
} 
que circulan en una determinada época. Con toda la cautela del caso, el diccionario ofrece un registro parcial de los cambios semánticos a lo largo del tiempo, lo que permite considerarlo como un índice tentativo de los que se operan en un vocablo.

Si en 1495 el Vocabulario español-latino de Antonio de Nebrija solo decía de 'colonia' que era una "ciudad de Alemania"67, para 1611, cuando el Imperio español se encontraba ya implantado en América, el Tesoro de la lengua castellana de Sebastián de Covarrubias la definía como "puebla o término de tierra que se ha poblado de gente estranjera, sacada de la ciudad, que es señora de aquel territorio, - llevada de otra parte", añadiendo que 'colonia' era el nombre del tipo de poblaciones establecidas por los romanos en España y en otros sitios ${ }^{68}$. De modo similar, en el primer diccionario de la Real Academia Española, editado entre 1726 y 1739, 'colonia' era definida como "poblacion ò término de tierra que se ha poblado de gente extrangera, trahida de la Ciudad Capital, ù de otra parte", y se añadía que "Ios Romanos llamaban también así a las que se poblaban de nuevo de sus antiguos moradores"69. Se introducía además la palabra 'colono', proveniente del latín colonus y ausente en diccionarios previos como los mencionados, a la que se definía como "el labradór que cultíva y labra alguna tierra por arrendamiento"70. En su edición de 1780, el diccionario de la Real Academia mantenía la definición de 'colonia' como "cierta porcion de gente que se envia de orden de algun príncipe, ó república á establecerse en otro país", pero se añadía que también designaba "el sitio, ó lugar donde se establecen"71. Pocos años después, el diccionario de Esteban de Terreros y Pando señalaba que 'colonia' remitía a "una partida, ó multitud de pueblo, que se envia á algun paraje lejano, y desierto, y de donde se suelen haber echado los habitadores para que los que se envian le desmonten, cultiven, y pueblen"72. Como puede advertirse, en este sentido que cabe denominar tradicional, 'colonia' equivalía a 'población'.

A comienzos del siglo XIX, la voz 'colonia' registraba cambios derivados de la reevaluación económica que la Corona española había hecho de sus dominios

\footnotetext{
67 Nebrija, Antonio de, Vocabulario español-latino, Impresor de la Gramática castellana, Salamanca, $1495,46$.

68 Covarrubias, Sebastián de, Tesoro de la lengua castellana o española, Luis Sánchez, Madrid, 1611, 448.

69 Real Academia Española, Diccionario de la lengua castellana, Imprenta de Francisco del Hierro, Madrid, $1729,419$.

70 Real Academia Española, Diccionario de la lengua castellana, 420.

71 Real Academia Española, Diccionario de la lengua castellana, Joachín Barra, Madrid, 1780, 243.

72 Terreros y Pando, Esteban, Diccionario castellano con las voces de ciencias y artes y sus correspondientes en las tres lenguas francesa, latina e italiana, Viuda de Ibarra, Madrid, 1786, 462.
} 
Ultramarinos73. En 1825, el diccionario de Manuel Núñez de Taboada incorporó la forma adjetiva 'colonial', para dar cuenta de aquello "de las colonias"74. La Real Academia incluyó por primera vez el mismo adjetivo en 1837, con el fin de indicar "/o perteneciente a la colonia", y también la forma verbal 'colonizar', para designar la acción de "formar ó establecer colonia en alguna parte"75. A esas expresiones, el diccionario de aquella institución incorporó en 1843 la de 'colonización', para referirse al "acto ó efecto de colonizar"76. Por otra parte, diccionarios como el de Ramón Joaquín Domínguez, de 1853, mantenían la tradicional definición de 'colonia' como un "número mas ó menos considerable de personas que se trasladan a un país con el objeto de poblarlo, perpetuándose en el lugar de su establecimiento"77.

Los cambios que el vocablo 'colonia' exhibía hacia el final del siglo XIX parecen registrar el impacto de la experiencia de las políticas de poblamiento impulsadas, entre otros, en países como Argentina, sobre todo a partir de la sanción de la Ley de Inmigración y Colonización (1876), con la que se dio una más decidida intervención de los poderes públicos en la materia78. Mientras que en sus ediciones de 1852 y 1869 el diccionario de la Real Academia definía como 'colonia' a una población enviada a formarse "en otro país", la de 1884 registraba un matiz significativo. En efecto, se añadía que 'colonia' podía también designar "gente que se establece en un territorio inculto de su mismo país para poblarle y cultivarle"79. Esa doble significación aparecía también en el diccionario publicado por Elías Zerolo en 1895, entre cuyas entradas para la palabra 'colonia' había una que refería a uno de los departamentos de la provincia argentina de Santa Fe, Las Colonias, y su cabecera, la Colonia Esperanza80.

73 Castejón, Philippe. "'Colonia' y 'metrópoli', la génesis de unos conceptos históricos fundamentales (1760-1808)”, Illes i Imperis, Barcelona, no. 18, 2016, 167.

74 Núñez de Taboada, Manuel, Diccionario de la lengua castellana, Seguin, París, 1825, 344.

75 Real Academia Española, Diccionario de la lengua castellana, Imprenta Nacional, Madrid, 1837, 179.

76 Real Academia Española, Diccionario de la lengua castellana, Imprenta de Francisco María Fernández, Madrid, 1843, 173.

77 Domínguez, Ramón Joaquín, Diccionario Nacional o Gran Diccionario Clásico de la Lengua Española, Establecimiento de Mellado, Madrid-París, 1853, 405.

78 Dicha ley dispuso la creación de una Oficina de Tierras y Colonias, dependiente del Ministerio de Agricultura y encargada de regular la formación y administración de las iniciativas de colonización emprendidas en el país. La oficina no constituyó nada parecido a un ministerio 'colonial' del tipo reclamado por Zeballos. Medidas similares también se llevaron adelante al otro lado del Atlántico, como en España, donde el gobierno de Antonio Maura sancionó en 1907 una ley de Colonización y Repoblación Interior. Pan Montojo, Juan, "De la agronomía a la ingeniería agronómica: la reforma de la agricultura y la sociedad rural españolas, 1855-1931", Áreas. Revista internacional de Ciencias Sociales, Murcia, no. 26, 2007, 75-93.

79 Real Academia Española, Diccionario de la lengua castellana, Gregorio Hernando, Madrid, 1884, 259.

80 Zerolo, Elías, Diccionario enciclopédico de la lengua castellana, Garnier hermanos, París, 1895, 622. 
Sin perjuicio de los sentidos económico-mercantiles que otros historiadores han identificado en el término 'colonia' para finales del siglo XVIII81, se advierte que aún un siglo más tarde la palabra mantenía la tradicional referencia a un tipo de población, con lo que estaba lejos de ser una voz inequívoca para designar las remotas posesiones de una metrópoli imperial. Ambos significados podían ser articulados en una misma enunciación, con usos descriptivos y metafóricos, como lo hizo en 1899 el presidente del Consejo General de Educación de Santa Fe, Domingo Guzmán Silva, para quien la realidad provincial mostraba que "las colonias son en muchos aspectos, así le duela a nuestro sentimiento nacional, verdaderas colonias, casi factorías como las que Inglaterra distribuye en Asia y en Africa, declarando resnullius aquellas tierras abrasadas por el sol"82.

Este breve excurso pone de relieve las capas semánticas acumuladas en el término 'colonia' al cabo de varios siglos y a su vez señala los sentidos simultáneamente disponibles hacia comienzos del siglo pasado, cuando el ministro Yofre expresaba -ipero en qué sentido?- que los Territorios constituían "propiamente colonias administradas por la Nación". A la luz del trayecto semántico esbozado, que muestra que la voz 'colonia' no dejó de remitir a un tipo de población, contemplar su uso como evidencia del carácter 'colonial' de los Territorios resulta precipitado. Cabe advertir que el proyecto de reforma que Yofre impulsó sin éxito en 1900 -del que se ha dicho que consideraba a los Territorios como "colonias internas del Estado nacional" 83- preveía que "si la instalación del concejo municipal se hiciese en el pueblo de una colonia nacional, será determinada con intervención del Ministerio de Agricultura, el área de terreno que deba considerarse como ejido de la planta urbana"84. Como puede advertirse, la expresión "colonia nacional" era allí empleada no como sinónimo de Territorio, sino para designar un tipo específico de localidad, nacida de una política de poblamiento organizado y no restringida a esos espacios, sino también promovida en la jurisdicción de las provincias.

Aun dejando de lado la cuestión de la condición de los Territorios -es decir, si es válido o no caracterizarla como 'colonial'-, contemplar el documento como un

81 Castejón, Phillipe, "'Colonia'”.

82 Gutiérrez, José María, Educación común en la Capital, provincias y territorios nacionales. año 1898. Informe presentado al Ministerio de Instrucción Pública, Imprenta M. Biedma e Hijo, Buenos Aires, $1899,87$.

83 Navarro Floria, Pedro, "La mirada", 92.

84 República Argentina, Antecedentes y motivos del proyecto de ley orgánica de los territorios nacionales, Jacobo Peuser, Buenos Aires, 1901, 191. 
testimonio directo de poder impide reconocer los usos pragmáticos de los conceptos, no solo aquellos orientados a denunciar un supuesto estado de disminución, como hacía Navarro Monzó, sino también a concitar el apoyo de funcionarios o legisladores a una determinada política, por ejemplo prestigiándola como emulación de los modelos burocrático-administrativos de las potencias imperiales europeas. Cualquiera fuese la intención de Yofre al referirse a los Territorios como 'colonias', resulta claro que si sus expresiones han llegado a ser tomadas sin más como evidencia de una condición 'colonial', es porque esa interpretación refleja el sentido que el concepto tiene en el imaginario de quien ha enfrentado el mismo documento en época más reciente. Esto obliga entonces a examinar la particular carga semántica que la voz 'colonia' adquirió en el tiempo transcurrido desde su uso por Yofre o Navarro Monzó, hasta su encuentro por la historiografía patagónica de inspiración poscolonial.

\section{Ideologemas coloniales}

De acuerdo a Annick Lempérière, durante siglos "la voz 'colonia' no tuvo ninguna connotación peyorativa" 85 , dado que -como pudo comprobarse más atráspor largo tiempo constituyó un término equivalente a población. Según lo sostenido por Phillipe Castejón, 'colonia' cobró en el siglo XVIII un novedoso significado económico, a partir del uso que se generalizó en la corte borbónica, que buscaba reformular el vínculo de la Corona con sus posesiones americanas en beneficio de esta86. Pero la crisis de la monarquía provocada por la invasión napoleónica imprimió a este uso un giro semántico que las revoluciones hispanoamericanas profundizaron, hasta convertir por primera vez al término en un concepto político para significar una condición disminuida e ilegítima. Este sentido se consolidó durante el siglo XIX, al ser utilizado por las clases dirigentes de las jóvenes repúblicas para tachar de legado español todo aquello que obstaculizaba la modernización de sus sociedades87.

85 Lempérière, Annick, "El paradigma colonial en la historiografía latinoamericanista", Istor. Revista de historia internacional, México, V, no. 19, 2004, 114.

86 Castejón, Phillipe, “'Colonia”", 177.

87 Lempérière, Annick, "El paradigma”, 111. Es ilustrativo que la palabra 'coloniaje' haya sido por primera vez incluida en un diccionario en 1895 -aunque ya era utilizada varias décadas atrás-, identificada como una voz de origen americano para designar "la época de la dominación española en las repúblicas americanas". Zerolo, Elías, Diccionario, 622. 
Según pudo observarse en la sección anterior, el uso de la voz 'colonia' en un sentido negativo, esto es, como indicativo de una condición de inferioridad respecto de la asumida como justa, se encontraba ya establecido en el ámbito hispanoamericano hacia finales del siglo XIX. En efecto, el uso metafórico que Navarro Monzó hacía del término tenía el propósito de señalar una degradación de estatus, como la que creía ver en los Territorios ante las provincias. Esa connotación negativa del término 'colonia', que no implicaba sin embargo una condena a la existencia de imperios con dominios coloniales, continuó siendo utilizada durante la primera mitad del siglo XX por distintos observadores de los Territorios para denotar lo que consideraban un tratamiento injusto de los gobiernos nacionales hacia estos espacios. En 1927, al inaugurar en la localidad patagónica de Río Gallegos el Congreso General de Territorios Nacionales, Manuel Carlés, el líder de la Liga Patriótica Argentina, denunciaba que "desde Buenos Aires, con su característica europea, los territorios aparecen al modo de colonias asiáticas o factorías, agregadas a la metrópoli por vínculos históricos o económicos"88. En el mismo sentido, hacia 1939 y desde el Territorio de Santa Cruz, el escritor Juan H. Lenzi reprochaba que "colonias internas, se ha llamado, con justicia, a los territorios, y lo son, de verdad, con tremenda injusticia para los territorianos y agravio para el espíritu institucional argentino"89. Y algunos años más tarde, el diputado Ernesto Sammartino exigía al Congreso de la Nación la inmediata conversión de los Territorios en nuevas provincias, para poner término a un régimen que los mantenía en la condición de "verdaderas colonias dentro de la República"90.

Pero en el curso del siglo XX se produjo un nuevo fenómeno. Como ha subrayado Lempérière, fue recién a partir de la expansión europea sobre Asia y África en el último tercio del siglo XIX, y de los juicios críticos elaborados acerca de ese proceso, que la voz 'colonia' adquirió una fuerte tonalidad ideológica, siendo entonces acuñados términos tales como 'imperialismo' y 'colonialismo' 91 . Como han

88 Liga Patriótica Argentina, Congreso General de Territorios Nacionales, celebrado en Río Gallegos. Febrero de 1927, Talleres Gráficos Argentinos J. L. Rosso, Buenos Aires, 1927, 50.

89 Lenzi, Juan Hilarión, Gobierno de territorios. Conceptos básicos de la Ley Orgánica Territorial, s/d, Buenos Aires, 1939, 66.

90 DSCD, 1947, I: 94, cit. en Navarro Floria, Pedro. “Planificación fallida y colonialismo interno en los proyectos estatales del primer peronismo (1943-1955) para la Patagonia", ponencia presentada en las IV Jornadas de Historia de la Patagonia, Bariloche, 2008, 11.

91 Lempérière, Annick, "El paradigma”, 111-112. Cabe advertir que el término 'colonialismo' fue por primera vez incluido en un diccionario de la Real Academia Española en 1970. Una vez más, esto no significa que la palabra no existiese hasta esa fecha. De todos modos, la contemporaneidad de la incorporación del término con los procesos de disolución de los imperios europeos en Asia y África invita a considerar los cambios lexicográficos como índice, 
planteado Osterhammel y Jansen, esa connotación negativa sedimentó en forma definitiva "con el surgimiento del nacionalismo anticolonial en el siglo XX [dado que] hasta entonces el dominio extranjero no fue considerado siempre como una ocupación extranjera ilegítima"92. A partir de los procesos de descolonización en Asia y África, el vocablo 'colonia' se cargó de un valor negativo que las teorías desarrollistas y dependentistas entonces en ascenso extrapolaron a los propios estados nacionales, para proponer concebir al "colonialismo como fenómeno integral, intercambiable de categoría internacional a categoría interna"93. Surgió así la noción compuesta de 'colonialismo interno', que, pese a los esfuerzos por darle tenor teórico, se mantuvo atada a aquella carga valorativa que hizo posible su enunciación. Fue esto mismo lo que aseguró su rápida adopción en el uso políticoideológico, en tanto servía para denunciar todo aquello que quisiera señalarse como obstáculo al desarrollo. Así ocurrió en Argentina con los grupos dirigentes surgidos en los Territorios luego de su transformación en nuevas provincias, que hicieron de la denuncia del 'colonialismo interno' la explicación de cada problema de sus realidades locales.

Un claro ejemplo de esto lo ofrece la dirigencia del Movimiento Popular Neuquino (MPN), partido que ha gobernado la provincia de Neuquén en forma ininterrumpida desde 1962, con los únicos paréntesis impuestos por los golpes de Estado ocurridos en el país94. En 1966, durante una reunión de gobernadores de provincias patagónicas celebrada en Buenos Aires meses antes del golpe de Estado de ese año, el gobernador Sapag decía hablar en nombre de toda la Patagonia al expresar que:

"seguimos siendo colonia, en esta Argentina grande que sólo piensa y actúa en la Pampa Húmeda. Colonia, porque se utilizan nuestros recursos básicos; colonia, porque no se aseguran nuestros legítimos derechos de paridad con el resto de la nación [...] El predomino económico del semicírculo de 300 km que

claro que aproximado, de transformaciones ostensiblemente más amplias. Real Academia Española, Diccionario de la lengua española, Espasa-Calpe, Madrid, 1970, 323.

92 Osterhammel, Jürgen y Jansen, Jan C., Colonialismo. Historia, formas, efectos, Siglo XXI, Madrid, 2019 [1995], 77. Itálicas en el original (Nota del editor: en referencia a la palabra aquí subrayada)

93 González Casanova, Pablo, Sociología de la explotación, CLACSO, Buenos Aires, [1969] 2006, 188.

94 El fundador y líder del partido, Felipe Sapag, fue elegido gobernador de Neuquén en 1962, 1963, 1973, 1983 y 1995, aunque en razón de sucesivos golpes de Estado solo pudo completar los dos últimos mandatos. A pesar de haber sido depuesto en 1966, fue designado interventor federal entre 1970 y 1972. 
bordea el gran Buenos Aires, fue en realidad una suerte de imperialismo interno ejercido por la Pampa Húmeda"95.

En 1973, poco después del triunfo electoral que lo convirtió de nuevo en gobernador, Sapag insistía en ese uso para acusar a los gobiernos nacionales de destrato hacia la provincia, que aportaba "elementos vitales para la nación -gas, petróleo, electricidad-", pero que sin embargo debía soportar que "no se hacen inversiones en la zona, salvo las indispensables para llevar nuestras riquezas y concentrarlas en ese gran puerto", de lo cual concluía que "ese trato colonial nos convierte en argentinos de tercera clase"16. Varias décadas más tarde, en su último mensaje de apertura legislativa, el gobernador Jorge Sapag, sobrino de Felipe y miembro del partido fundado por su tío, volvía sobre el mismo motivo, ya tradicional en dicha fuerza. Para Sapag, el régimen federal consagrado en la Constitución nacional se veía desmentido por fuerzas centralistas, que lo llevaban a afirmar que "la lucha por el federalismo con vigencia real, es una lucha de todos los días, para terminar con un siglo de colonialismo y dominación de nuestros recursos y para finalizar también con las causas de desigualdades territoriales, económicas y sociales"97.

Los alegatos de los gobernadores ponen de manifiesto la duradera presencia del tópico del 'colonialismo' entre las dirigencias políticas de los ex Territorios, incluidas aquellas que permanecieron siempre en la oposición. Desde La Pampa, gobernada sin interrupción por el peronismo desde 1983, el radical Antonio Berhongaray, durante casi dos décadas legislador nacional por dicha provincia, afirmaba, en un ensayo publicado al término del siglo pasado, que los Territorios "constituyeron el equivalente de los imperios coloniales foráneos"98 y desde tal premisa se interesaba en la posibilidad de "efectuar un estudio comparativo entre la descolonización del África y otros pueblos colonizados de otros continentes y el proceso de provincialización de los 'territorios nacionales' argentinos"99. El objetivo de Berhongaray era claro: "arrojar luz sobre ciertas postergaciones actuales", que creía derivaban de que "en el

\footnotetext{
95 “Reunión extraordinaria de gobernadores de la Patagonia", en Sapag, Felipe, El desafío, Spring, Temuco, $1994,97$.

96 Análisis confirmado, Buenos Aires, no. 632, 24-30 de abril de 1973.

97 Diario de Sesiones de la Legislatura de Neuquén (DSLN), "Mensaje del gobernador Jorge Sapag con motivo de la inauguración del XLIV periodo de sesiones ordinarias de la Legislatura de Neuquén", 10 de marzo de 2015, 27.

98 Berhongaray, Antonio T., La Pampa y la lucha por su autonomía. El fin del colonialismo interno argentino, Fipros, Buenos Aires, 2000, 17.

99 Berhongaray, Antonio T., La Pampa y la lucha por su autonomía, 23.
} 
inconsciente de muchos argentinos con poder, las provincias que fueron territorios nacionales continúan siendo vivenciadas de una forma desvalorizada"100.

Estos usos políticos, que denuncian la imposición de una relación 'colonial' a los Territorios desde su misma creación, son coincidentes con aquella historiografía que décadas más tarde ha venido a sostener lo mismo desde el ámbito académico. Como dos investigadores inspirados en la literatura poscolonial señalaban en una entrevista al diario más importante de la Patagonia, la toma de esa región por el Estado argentino "tiene muchas similitudes con esas prácticas de expansión colonial" -en referencia a las desplegadas por los imperios europeos en África-y a ello atribuían el hecho de que a "Ios territorios nacionales se los consideró como una colonia dentro del país", algo que se comprobaría, por ejemplo, al advertir que "en 1899, Zeballos le dijo al presidente Roca que los territorios nacionales necesitaban una burocracia colonial al modo de los británicos"101. Se ha postulado así, de forma similar a las representaciones del pasado ofrecidas por los propios actores políticos -"un siglo de colonialismo", en los términos de Sapag-, la existencia de una "lógica colonial interna de acuerdo con la cual fue construida desde fines del siglo XIX la relación entre el Estado nacional y los Territorios Nacionales"102. Desde entonces, se habría implantado "un modelo extractivo de vinculación entre los Territorios y el Estado nacional", a cuya reproducción servían "las reglas del juego colonial que se aplicaban a los Territorios"103. Política e historiografía confluyen así en una imagen de la historia patagónica que la reduce a una pura continuidad.

Aun cuando responden a diferentes propósitos, la concordancia entre ambas representaciones del pasado no es accidental. La significación negativa del término 'colonia' constituye el sustrato común del que derivan. No obstante su afán crítico, al emplear como instrumento de análisis aquello que no reconoce como un específico sentido valorativo del término, esa historiografía tiende a reforzar la eficacia simbólica de un discurso político que la antecede en varias décadas y que, según algunos enfoques, constituye una de las bases de duraderas hegemonías políticas

\footnotetext{
100 Berhongaray, Antonio T., La Pampa y la lucha por su autonomía, 22.

101 “'A los territorios se los consideró como una colonia dentro del país'. Entrevista a Perla Zusman y Pedro Navarro Floria", Río Negro [online], 4/2/2007.

102 Núñez, Paula Gabriela y Navarro Floria, Pedro, "El desarrollo patagónico en el epílogo territoriano”, en Núñez, Paula G. comp., Sombras del desarrollo. La Patagonia de la energía y la formación de la provincia de Río Negro, Universidad Nacional de Río Negro, Bariloche, 2016, 43.

103 Navarro Floria, Pedro, "La mirada", 87-91.
} 
provinciales ${ }^{104}$. Cabe incluso preguntarse hasta qué punto el interés por revelar los orígenes de un régimen 'colonial' interno no da cuenta de la participación, quizá inadvertida, de esa historiografía en esos imaginarios locales. Sumergida en el ideologema 'colonial' e incitada a permanecer allí bajo la sugestión de una corriente poscolonial que solo pudo desarrollarse a partir de él, la historiografía patagónica inspirada en esa literatura encuentra dificultades para ir más allá de la textualidad de los documentos y queda comprometida en la reproducción de un cierto imaginario político. Al trabajar a partir de la carga ideológica del término, sin identificar las posibilidades semánticas disponibles en un determinado campo de experiencia, aquel preciso sentido resulta sin más tomado como el único. Solo de ese modo llega a ser posible encontrar en un documento la palabra 'colonia' y convertirla en evidencia de un régimen 'colonial'.

\section{Conclusiones}

En este artículo se ha buscado llamar la atención sobre algunos de los riesgos derivados de la fascinación por ciertas corrientes intelectuales proclives a reducir los fenómenos históricos a sus manifestaciones discursivas y que promueven formas de examinación de la evidencia documental que tienden a concebirla como mero texto. En particular, se ha querido advertir el peligro de descuidar un aspecto tradicional pero aún fundamental de la práctica historiográfica como es el de la crítica documental. En el ejemplo examinado, el abandono de ese principio metodológico básico al calor del entusiasmo por la adopción de ciertas interpretaciones ha favorecido un abordaje textualista de las fuentes, en el que los sentidos de los conceptos articulados en ellas son tomados como inequívocos e inmutables y luego empleados como verificaciones de lo postulado por la literatura de la que se abreva. Así ha manejado la historiografía patagónica de molde poscolonial el vocablo 'colonia' al dar con él en las fuentes documentales, haciendo de la mera presencia del término una evidencia de un régimen o de una condición 'colonial'.

\footnotetext{
104 Favaro, Orietta, "Sociedad y política. La interpelación y representación política de los ciudadanos neuquinos. Neuquén, Argentina (1958-1983)", Prohistoria, Rosario, VIII, no. 8, 2004, 151-163; Favaro, Orietta, "Neuquén (Argentina) en clave política. Estado y partido, 1961-1991", Estudios sociales del Estado, Rosario, III, no. 6, 2014, 191217.
} 
Como pudo observarse, la experiencia de la disolución de los imperios europeos a partir de mediados del siglo pasado, marcada por una crítica tanto intelectual como política del 'colonialismo', cargó a la voz 'colonia' de un intenso valor negativo del que nunca pudo liberarse. El proceso de progresiva criminalización del fenómeno que entonces cobró impulso no se limitó al derecho internacional, sino que avanzó en forma paralela en otros ámbitos académicos, que incorporaron a su acervo terminológico un concepto ya marcado por una fuerte carga ideológica. Algunos se constituyeron como disciplinas a partir de esa resemantización negativa, como es el caso de los propios estudios poscoloniales. Ese sentido valorativo terminó por extenderse a toda la familia lingüística de la voz 'colonia', decantando en un estrato semántico que sepultó otras significaciones del concepto que se volvieron de más difícil restitución. Fue solo como resultado de ese cambio semántico que la palabra 'colonia' pudo ser convertida en sinónimo de 'colonialismo'. Y fue debido a esa previa igualación de valor que llegó a ser posible encontrar aquel término en un documento y hacerlo evidencia de este otro fenómeno. En el caso aquí analizado, el atractivo político-ideológico de la literatura poscolonial animó a ese salto hermenéutico, que a su vez orientó la indagación en las fuentes documentales hacia la detección de constataciones textuales de ese modelo consagrado, e indujo a considerar la experiencia histórica de espacios como la Patagonia como mera iteración local de un mismo 'proyecto colonial' como el desplegado por los imperios europeos sobre Asia y África en las décadas finales del siglo XIX.

No se pretende argumentar que, debido al peso de tal carga semántica, esa historiografía no podía haber escapado a la interpretación que hizo del término 'colonia'. Por el contrario, lo que se ha intentado destacar es la necesidad de discriminar las capas semánticas contenidas en un concepto, ya que su reposición es indispensable para proteger el pensamiento histórico -en la conceptualización de Michael Oakeshott, una forma específica de pensar sobre el pasado- de su asedio por los compromisos que, de modo voluntario o inadvertido, empujan al historiador a usos ya superficiales, ya instrumentales del pasado 105. En este sentido, antes que reflejar un rasgo idiosincrásico, el abordaje que la historiografía examinada ha hecho de sus fuentes más bien ilustra los problemas de una insuficiente atención a los

105 Oakeshott, Michael, Sobre la historia, 39-40. 
cambios semánticos operados en el curso del tiempo, que resultan así velados por una doble reducción: la del documento a texto y la de la realidad histórica a discurso.

Es indudable que los documentos constituyen articulaciones lingüísticas, pero también que las acciones prácticas de las que aquellas son vestigios no son nunca productos exclusivos del discurso ${ }^{106}$. Lo explorado en estas páginas revela que la adopción entusiasta de enfoques que se ordenan desde la premisa de una constitución lingüística de la realidad conlleva los riesgos de reducir la historia a sus condensaciones discursivas y de imaginar que ella se trasluce en la superficie de las fuentes. Estas pasan así a ser recorridas en su textualidad, en busca de palabras que son tomadas como comprobaciones inequívocas de lecturas que, en realidad, como pudo observarse, arrastran pesadas cargas valorativas. Ante la vigencia de tales prácticas, no puede dejar de subrayarse la necesidad de distinguir las capas de sentido acumuladas en los conceptos modulados en las fuentes y advertir así, aun cuando pueda parecer trivial, que las coincidencias lexicográficas no suponen correspondencias semánticas.

Fecha de recepción: 29/07/21

106 Chartier, Roger, El mundo como representación: estudios sobre historia cultural, Barcelona, Gedisa, 2005, IX; Koselleck, Reinhart, Historias, 14. 


\section{Referencias Bibliográficas}

Appleby, Joyce; Hunt, Lynn y Jacob, Margaret, La verdad sobre la historia, Andrés Bello, Santiago de Chile, 1999 [1995].

Berhongaray, Antonio T., La Pampa y la lucha por su autonomía. El fin del colonialismo interno argentino, Fipros, Buenos Aires, 2000.

Campión, Arturo, Discursos políticos y literarios, Imprenta y Librería de Erice y García, Pamplona, 1907.

Castejón, Philippe, “'Colonia' y 'metrópoli', la génesis de unos conceptos históricos fundamentales (1760-1808)", Illes i Imperis, Barcelona, no. 18, 2016, 163-179.

Chartier, Roger, El mundo como representación: estudios sobre historia cultural, Barcelona, Gedisa, 2005.

Chartier, Roger, On the Edge of the Cliff. History, Languages, and Practices, John Hopkins University Press, Baltimore, 1997.

Covarrubias, Sebastián de, Tesoro de la lengua castellana o española, Luis Sánchez, Madrid, 1611.

Derrida, Jacques, Mal de archivo. Una impresión freudiana, Trotta, Madrid, 1997 [1995].

Domínguez, Ramón Joaquín, Diccionario Nacional o Gran Diccionario Clásico de la Lengua Española, Establecimiento de Mellado, Madrid-París, 1853.

Favaro, Orietta, "Sociedad y política. La interpelación y representación política de los ciudadanos neuquinos. Neuquén, Argentina (1958-1983)", Prohistoria, Rosario, VIII, no. $8,2004,151-163$.

Favaro, Orietta, "Neuquén (Argentina) en clave política. Estado y partido, 1961-1991", Estudios sociales del Estado, Rosario, III, no. 6, 2014, 191-217.

Foucault, Michel, El orden del discurso, Tusquets, Buenos Aires, 1992 [1970].

Foucault, Michel, Las palabras y las cosas, Fondo de Cultura Económica, México, 2002 [1966].

Foucault, Michel, La arqueología del saber, Siglo XXI, Buenos Aires, 2003 [1969].

Fradera, Josep, Gobernar colonias, Península, Barcelona, 1999.

González Casanova, Pablo, Sociología de la explotación, Clacso, Buenos Aires, 2006 [1969].

Gutiérrez, José María, Educación común en la Capital, provincias y territorios nacionales. año 1898. Informe presentado al Ministerio de Instrucción Pública, Imprenta M. Biedma e Hijo, Buenos Aires, 1899. 
Harambour, Alberto, "Monopolizar la violencia en una frontera colonial. Policías y militares en Patagonia austral (Argentina y Chile, 1870-1920)", Quinto Sol, Santa Rosa, XX, no. 1, 2016, 1-27.

Harambour, Alberto, Soberanías fronterizas. Estados y Capital en la Colonización de Patagonia (Argentina y Chile, 1830-1922), Universidad Austral de Chile, Valdivia, 2019.

Koselleck, Reinhart, Futuro pasado. Para una semántica de los tiempos históricos, Paidós, Barcelona, 1993 [1979].

Koselleck, Reinhart, Historias de conceptos. Estudios sobre semántica y pragmática del lenguaje político y social, Trotta, Madrid, 2012 [2006].

Koselleck, Reinhart, Sediments of Time. On Possible Histories, Stanford University Press, Stanford, 2018 [2000].

Le Bon, Sylvie, "Nota preliminar. Un positivista desesperado: Michel Foucault", en Foucault, Michel, Saber, historia y discurso, Prometeo, Buenos Aires, 2015, 9-30.

Lempérière, Annick, "El paradigma colonial en la historiografía latinoamericanista". Istor. Revista de historia internacional, México, V, no. 19, 2004, 107-128.

Lenzi, Juan Hilarión, Gobierno de territorios. Conceptos básicos de la Ley Orgánica Territorial, s/d, Buenos Aires, 1939.

Liga Patriótica Argentina, Congreso General de Territorios Nacionales, celebrado en Río Gallegos. Febrero de 1927, Talleres J. L. Rosso, Buenos Aires, 1927.

López, Lucio V., Derecho administrativo argentino, Imprenta de La Nación, Buenos Aires, 1902.

Lyotard, Jean-François, La condición posmoderna, REI Argentina, Buenos Aires, 1995 [1979].

Mellino, Miguel, La crítica poscolonial. Descolonización, capitalismo y cosmopolitismo en los estudios poscoloniales, Paidós, Buenos Aires, 2008.

Monzó, Julio, "Los tres problemas del momento político actual", Revista Argentina de Ciencias Políticas, Buenos Aires, VI, 1913.

Navarro Floria, Pedro, "La nacionalización fallida de la Patagonia Norte. 1862-1904", Quinto Sol, Santa Rosa, VII, no. 1, 2003, 61-91.

Navarro Floria, Pedro (comp.), Patagonia: ciencia y conquista. La mirada de la primera comunidad científica argentina, Publifadecs, General Roca, 2004.

Navarro Floria, Pedro, "La 'República posible' conquista el 'desierto'. La mirada del reformismo liberal sobre los Territorios del Sur argentino", en Navarro Floria, Pedro coord., Paisajes del progreso. La resignificación de la Patagonia norte, 1880-1916, Educo, Neuquén, 2007, 191-234. 
Navarro Floria, Pedro, "El conocimiento de los Territorios Nacionales generado por los agentes del Estado: memorias, informes y mapas", en Podgorny, Irina; Penhos, Marta y Navarro Floria, Pedro, Espacios y cuerpos en la Argentina del siglo XIX y comienzos del XX, Biblioteca Nacional-Teseo, Buenos Aires, 2007, 89-114.

Navarro Floria, Pedro. "Planificación fallida y colonialismo interno en los proyectos estatales del primer peronismo (1943-1955) para la Patagonia", ponencia presentada en las IV Jornadas de Historia de la Patagonia, Bariloche, 2008.

Navarro Floria, Pedro. "La mirada del reformismo liberal sobre los Territorios del Sur argentino, 1898-1916”. Quinto Sol, Santa Rosa, no. 13, 2009, 73-103.

Navarro Floria, Pedro y Núñez, Paula Gabriela, "Un territorio posible en la República imposible. El Coronel Sarobe y los problemas de la Patagonia argentina", Andes, Salta, XXIII, no. 2, 2012. En: http://www.scielo.org.ar/pdf/andes/v23n2/v23n2a06.pdf. Acceso: 25-3-2019.

Navarro Monzó, Julio, "Informe del secretario privado del señor Ministro del Interior, con motivo de su viaje a los Territorios de la Pampa, Neuquén, Río Negro, Chubut y Santa Cruz", en Ministerio del Interior, Primera Conferencia de los Gobernadores de Territorios Nacionales, Talleres gráficos de la Penitenciaría Nacional, Buenos Aires, 1913.

Nebrija, Antonio de, Vocabulario español-latino, Impresor de la Gramática castellana, Salamanca, 1495.

Núñez de Taboada, Manuel, Diccionario de la lengua castellana, Seguin, París, 1825.

Núñez, Paula Gabriela y Navarro Floria, Pedro, "El desarrollo patagónico en el epílogo territoriano", en Núñez, Paula G. comp., Sombras del desarrollo. La Patagonia de la energía y la formación de la provincia de Río Negro, Universidad Nacional de Río Negro, Bariloche, 2016, 12-47.

Oakeshott, Michael, Sobre la historia y otros ensayos, Katz, Buenos Aires, 2013.

Osterhammel, Jürgen y Jansen, Jan C., Colonialismo. Historia, formas, efectos, Siglo XXI, Madrid, 2019 [1995].

Pan Montojo, Juan, "De la agronomía a la ingeniería agronómica: la reforma de la agricultura y la sociedad rural españolas, 1855-1931". Areas. Revista internacional de Ciencias Sociales, Murcia, no. 26, 2007, 75-93.

Pi y Margall, Francisco, Historia de la América antecolombiana, 2 vols., Montaner y Simón, Barcelona, 1, 1892.

Pratt, Mary Louise, Ojos imperiales. Literatura de viajes y transculturación, Fondo de Cultura Económica, Buenos Aires, 2011 [1992].

Real Academia Española, Diccionario de la lengua castellana, Imprenta de Francisco del Hierro, Madrid, 1729. 
Real Academia Española, Diccionario de la lengua castellana, Joachín Barra, Madrid, 1780.

Real Academia Española, Diccionario de la lengua castellana, Viuda de Ibarra, Madrid, 1803.

Real Academia Española, Diccionario de la lengua castellana, Imprenta Nacional, Madrid, 1837.

Real Academia Española, Diccionario de la lengua castellana, Imprenta de Francisco María Fernández, Madrid, 1843.

Real Academia Española, Diccionario de la lengua castellana, Gregorio Hernando, Madrid, 1884.

Real Academia Española, Diccionario de la lengua castellana, Imprenta de los señores Hernando y compañía, Madrid, 1899.

Real Academia Española, Diccionario de la lengua española, Espasa-Calpe, Madrid, 1970.

Real Academia Española, Diccionario de la lengua española, Espasa-Calpe, Madrid, 1992.

República Argentina, Antecedentes y motivos del proyecto de ley orgánica de los territorios nacionales. Buenos Aires: Jacobo Peuser, 1901.

Sapag, Felipe, El desafío, Spring, Temuco, 1994.

Skinner, Quentin, Lenguaje, política e historia, Universidad Nacional de Quilmes, Bernal, 2007 [2002], 33-61.

Terreros y Pando, Esteban, Diccionario castellano con las voces de ciencias y artes y sus correspondientes en las tres lenguas francesa, latina e italiana, Viuda de Ibarra, Madrid, 1786.

Unamuno, Miguel de, Ensayos, 7 vols., Publicaciones de la Residencia de Estudiantes, Madrid, III, 1916-1918.

White, Hayden, Metahistoria. La imaginación histórica en la Europa del siglo XIX, México, Fondo de Cultura Económica, 1992 [1973].

White, Hayden, El texto histórico como artefacto literario y otros escritos, barcelona, páidós, 2003.

Windschuttle, Keith, The Killing of History. How Literary Critics and Social Theorists are Murdering Our Past, The Free Press, New York, 1996.

Young, Robert C. J., "Nuevos recorridos por (las) Mitologías blancas", en Mezzadra, Sandro comp., Estudios poscoloniales. Ensayos fundamentales, Traficantes de sueños, Madrid, 2008.

Zeballos, Estanislao, "De Magallanes a la Puna", Revista de Derecho, Historia y Letras, Buenos Aires, I, no. 3, 1899, 308-315. 
Zerolo, Elías, Diccionario enciclopédico de la lengua castellana, Garnier hermanos, París, 1895.

Zusman, Perla, "La alteridad de la nación. La formación del Territorio del Noroeste del Río Ohio de los Estados Unidos (1787) y de los Territorios Nacionales en Argentina (1884)", Documents d'Anàlisi Geogràfica, Barcelona, no. 56, 2010, 503-524. 